\title{
Sociodemographic Determinants of Patients' Satisfaction with the Quality of Care in the General Hospitals in Ebonyi State, Nigeria
}

\author{
MaryJoy Umoke ${ }^{1}$, Prince Christian Ifeanachor Umoke ${ }^{2}$, Nora Eyo ${ }^{3}$, Adaeze $\mathrm{Ugwu}^{3}$, Martins Nonso $\mathrm{Agu}^{4}$, Obinna \\ Jude Chukwu ${ }^{5}$, David Onyemaechi Eke ${ }^{6}$, Patrick Ogbodo Njoku ${ }^{7}$, Chioma Adaora Nwalieji ${ }^{2}$, Rosemary N. Onwe ${ }^{8}$, \\ Ignatius O. Nwimo ${ }^{9}$, Ugochi Georgina Umoke ${ }^{10}$ \& Ifeanyi Emmanuel Nwafor ${ }^{11}$ \\ ${ }^{1}$ School Health Programme Unit Ebonyi State Ministry of Health Abakaliki, Nigeria \\ ${ }^{2}$ Department of Human Kinetics and Health Education, University of Nigeria Nsukka, Nigeria \\ ${ }^{3}$ World Health Organization country Office, No. 1 Onwe road, Abakaliki, Nigeria \\ ${ }^{4}$ Ananda Marga Universal Relief Team Foundation, Plot 26 Onwe Road Extension, Abakaliki, Ebonyi State, \\ Nigeria \\ ${ }^{5}$ Alex Ekwueme Federal University Teaching Hospital Abakaliki, Nigeria \\ ${ }^{6}$ Education Foundation, Alex Ekwueme Federal University Ndufu Alike Ikwo, Ebonyi State, Nigeria \\ ${ }^{7}$ Primary Healthcare Department, Ebonyi State Ministry of Health Abakaliki, Nigeria \\ ${ }^{8}$ Department of Economics, Ebonyi state university, Abakaliki, Nigeria \\ ${ }^{9}$ Department of Human Kinetics and Health Education, Ebonyi State University, Abakaliki, Nigeria \\ ${ }^{10}$ University of Nigeria Teaching Hospital, Ituku Ozalla Enugu, Nigeria \\ ${ }^{11}$ Virology Centre Laboratory, Alex Ekwueme Federal University Teaching Hospital Abakaliki, Nigeria \\ Correspondence: MaryJoy Umoke, Ebonyi State Ministry of Health Abakaliki, Nigeria. Tel: 234- 806-232-5890. \\ E-mail: maryjoy4umoke@gmail.com
}

Received: June 12, 2020 Accepted: July 24, 2020 Online Published: September 4, 2020

doi:10.5539/gjhs.v12n11p7 URL: https://doi.org/10.5539/gjhs.v12n11p7

\begin{abstract}
Introduction: The purpose of the study was to assess sociodemographic determinants of patients' satisfaction with the quality of care in the General Hospitals in Ebonyi State. Four hypotheses were formulated for the study. Demographic characteristics of age, level of education, marital status, and income level on patients' satisfaction were ascertained.
\end{abstract}

Methods: A cross-sectional survey research design was used for the study. The population of the study comprised 1, 363, 633 (18 years and above) who attended general out-patient clinics in the General Hospitals using a sample of 400. Data were analyzed using mean $(\bar{X})$, t-test, and analysis of variance (ANOVA) were used to answer the hypothesis at 0.05 level of significance. The SPSS version 20 was employed for the analysis.

Results: Findings showed that patients who were 40-60 years $(\bar{x}=2.96)$, had tertiary education $(\bar{x}=2.97)$, earned income of N40, $000-\mathrm{N} 59,000(\bar{X}=2.96)$ and were married $(\bar{X}=3.09)$ were most satisfied. Besides, age, marital status, and income were not significantly associated $(\mathrm{p}>0.05)$ with patients' satisfaction while the level of education was significant $(\mathrm{p}<0.05)$.

Conclusion: The study revealed that older age, more educated, middle-class income earners, being married were more satisfied with the quality of care received. Efforts should be made by Health workers to ensure that all patients are satisfied irrespective of their demographic characteristics.

Keywords: patient, satisfaction, sociodemographic variables

\section{Introduction}

The health sector in any economy forms the bedrock of its growth and development. An effective and efficient health sector not only meet the health needs of the citizenry but also boost the nation's Gross Domestic Product (GDP) by generating enormous revenue to the government and a healthy citizenry. Thus the provision of quality health services is indispensable, yet the health care delivery system in Nigeria is characterized by problems of 
quality of care and accessibility to care (Anyika, 2014; Shagaya, 2015). Patient satisfaction has emerged as an essential index to determine the excellence of care (Surur, Teni, Girmay, Moges, Tesfa, \& Abraha, 2015). Hospital routine can be best assessed by measuring the level of patient satisfaction with communication between health workers and patients which has been reported as very poor, these have made them to be at the mercy of the health care workers in those hospitals (Alrubaiee, \& Alkaa'ida, 2011; Zhang, Wang, Yu, \& Zhao, 2018; Chandra, Ward, \& Mohammadnezhad, 2019) For most countries, research on patients' satisfaction and patients' experience with hospitals are done most often and the feedback gotten are made available to the public together with other indicators of health care quality. The hospitals in the developed countries are aware of the consequence of delivering patient approval as a tactical variable and a vital determinant of long-term feasibility and success (Amole, Oyetoye, \& Kuye, 2015). Unfortunately, patients' satisfaction with the quality of health services provided in the nation's hospitals seemed to have been for the most part overlooked by health care managers, hospital administrators, politicians, and other decision-makers in the sector. Thus, patients choose health care based on the satisfaction they received from various health facilities. Consequently, this resulted in an astronomical increase of medical tourism by Nigerians abroad for even cases that can be managed successfully by our health sector with a depletion of the nation's foreign reserves. For instance, about 78 billion naira (over 8,500 million US dollars) is spent by Nigerians yearly to seek health care services abroad mainly from seeming shortcoming in the home health care delivery organization (Megbelayin, Babalola, Kurawa, Opubiri, \& Okonkwo, 2015).

Furthermore, any strategy to promote self-reliance and encourage the usage of the existing hospitals must utilize patients' voices as a guide in the design of the health sector. To reverse this ugly trend, several survey studies have been conducted to assess patients' satisfaction in Nigerian hospitals, though they are insufficient for policymaking. Even though Ebonyi state government runs 13 general hospitals that are sited in the 13 LGAs and 424 primary health care centers, there is low patronage as there is a surge of patients in tertiary and private health facilities even for ailments that can be treated at their facilities. It is to this end that this research was set to explore the Sociodemographic determinants of patients' satisfaction in state-owned General Hospitals in all the Local Government Area of Ebonyi State, Nigeria using demographic variables such as age, gender, and educational level. Four hypotheses guided this study and were tested at $\mathrm{p}<0.05$ level of significance.

\subsection{Hypotheses}

1) There is no significant difference in patients' satisfaction based on age.

2) There is no significant difference in patients' satisfaction based on the Educational level.

3) There is no significant difference in patients' satisfaction based on marital status.

4) There is no significant difference in patients' satisfaction based on income.

\section{Methods}

\subsection{Research Design}

The study adopted the descriptive survey research design. This design was considered appropriate and adequate for this study because it has been used in previous studies by Karaca and Durna, (2019). The researcher recruited a sample size from the larger populace to explore and interpret the status of outpatients' satisfaction with the quality of care in the hospitals in Ebonyi State.

\subsection{Area of the Study}

The study was carried out in Ebonyi state, which occupies a land area of 5,954 square kilometers and is situated between longitude 70 and $80301 \mathrm{E}$ and latitude 50401 and 60541 north of the equator. The state is part of the southeast geopolitical zone and bounded in the north by Benue state, in the west by Enugu state, in the east by Cross River State and in the south by Abia state. The population of Ebonyi state for 2016 is 2, 64,776 (projected from 2006 census of 2,173,501 with a projected growth rate of $2.8 \%$ ). The population of male and female are $1,416,334$ (48.62\%) and 1,481,067 (51.38\%) respectively, children under 5 years were 579,480 (20\%), pregnant women were $144,870(5 \%)$ and women of childbearing age is $637,428(22 \%)$. Nearly $75 \%$ of the State population is engaged in subsistent agrarian economic activities. The economy is majorly driven by the public sector and $56 \%$ of the population lives below U\$1 per day (GDP) with high levels of unemployment and underemployment and with very few industries with low output. The state runs a three-tier health care system which are primary, secondary, and tertiary levels. The Federal government is responsible for tertiary healthcare which is the apex of the healthcare delivery and provides specialized services through the Federal Teaching Hospital Abakaliki (FETHA), Vesico-Vaginal Fistula (VVF) center. The state provides care through the 13 General Hospitals and 6 Rural Mission Hospital while the Local Government Council takes care for Primary Health Care Services. There 
are 555 health facilities in the state, consisting of 2 tertiary health facilities, 13 government hospitals, 424 primary health care centers, 6 rural mission hospitals, and 110 health private facilities (Ebonyi State Ministry of Health., 2016).

\subsection{Population of the Study}

According to the 2016 projected population, 1,363,633 constitute a population of adults 18 years and above (Figure 1), with the Abakaliki education zone having a population of 448,538, Onueke education zone 407,737, and Afikpo education zone 518,818.

\begin{tabular}{|c|c|c|c|c|c|c|c|c|c|c|c|c|c|}
\hline $\begin{array}{l}\text { District_o } \\
\text { ame }\end{array}$ & & $\begin{array}{l}\text { Total } \\
\text { Populatio } \\
\text { n of the } \\
\text { District } \\
\text { (2015) }\end{array}$ & $\begin{array}{l}\text { Gro } \\
\text { wth } \\
\text { Rate } \\
(2.8 \\
\%)\end{array}$ & $\begin{array}{c}\text { Total } \\
\text { Popula } \\
\text { tion of } \\
\text { the } \\
\text { Distric } \\
\text { t 2016 }\end{array}$ & $\begin{array}{c}\text { Pregna } \\
\text { nt } \\
\text { Wome } \\
n\end{array}$ & $\begin{array}{c}\text { Popula } \\
\text { tion } \\
\text { Under } \\
\text { 1/Birth } \\
\text { Cohort }\end{array}$ & $\begin{array}{c}\text { Popula } \\
\text { tion } \\
\text { Under } \\
5\end{array}$ & 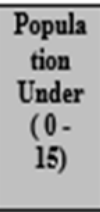 & $\begin{array}{c}\text { above } \\
18 \\
\text { years } \\
(48 \%)\end{array}$ & $\begin{array}{l}\text { 6- } \\
59 \mathrm{mt} \\
\mathrm{hs}\end{array}$ & $\begin{array}{l}\text { 6- } \\
\text { llmt } \\
\text { hs }\end{array}$ & $\begin{array}{l}\text { 12- } \\
59 \mathrm{mt} \\
\mathrm{hs}\end{array}$ & $\begin{array}{c}\text { WCB } \\
A\end{array}$ \\
\hline & & & & $(2.8 \%)$ & \multicolumn{2}{|c|}{ RI } & SIAs & AFP & & $\begin{array}{l}\text { Vita } \\
\text { A }\end{array}$ & $\begin{array}{l}\text { Vita } \\
\mathrm{A}\end{array}$ & $\begin{array}{l}\text { Vita } \\
\mathrm{A}\end{array}$ & \\
\hline Abakaliki & 20 & 194.531 & 5.447 & $\begin{array}{r}199,97 \\
8\end{array}$ & 9.999 & 7.999 & 39.996 & 95.189 & 95.989 & $\begin{array}{r}3599 \\
6\end{array}$ & 4000 & $\begin{array}{r}3199 \\
6\end{array}$ & 43995 \\
\hline $\begin{array}{l}\text { Afikpo } \\
\text { North }\end{array}$ & 16 & 200,798 & 5.622 & $\begin{array}{r}206,42 \\
0 \\
\end{array}$ & 10,321 & 8.257 & 41,284 & 98,256 & 99,082 & $\begin{array}{r}3715 \\
6 \\
\end{array}$ & 4128 & $\begin{array}{r}3302 \\
7 \\
\end{array}$ & 45412 \\
\hline $\begin{array}{l}\text { Afikpo } \\
\text { South } \\
\end{array}$ & 13 & 201.389 & 5.639 & $\begin{array}{r}207,02 \\
8 \\
\end{array}$ & 10,351 & 8.281 & 41,406 & 98,545 & 99,373 & $\begin{array}{r}3726 \\
5 \\
\end{array}$ & 4141 & $\begin{array}{r}3312 \\
4 \\
\end{array}$ & 45546 \\
\hline Ebonyi & 20 & 162,624 & 4,553 & $\begin{array}{r}167,17 \\
7 \\
\end{array}$ & 8,359 & 6,687 & 33,435 & 79,576 & 80,245 & $\begin{array}{r}3009 \\
2\end{array}$ & 3344 & $\begin{array}{r}2674 \\
8\end{array}$ & 36779 \\
\hline $\begin{array}{l}\text { Exza } \\
\text { North } \\
\end{array}$ & 15 & 186,705 & 5.228 & $\begin{array}{r}191,93 \\
3 \\
\end{array}$ & 9,597 & 7,677 & 38,387 & 91.360 & 92.128 & $\begin{array}{r}3454 \\
8 \\
\end{array}$ & 3839 & $\begin{array}{r}3070 \\
9 \\
\end{array}$ & 42225 \\
\hline $\begin{array}{l}\text { Exza } \\
\text { South }\end{array}$ & 19 & 170,788 & 4,782 & $\begin{array}{r}175,57 \\
0 \\
\end{array}$ & 8,779 & 7,023 & 35,114 & 83,571 & 84,274 & $\begin{array}{r}3160 \\
3 \\
\end{array}$ & 3511 & $\begin{array}{r}2809 \\
1 \\
\end{array}$ & 38625 \\
\hline Inte & 30 & 275,154 & 7,704 & $\begin{array}{r}282,85 \\
8 \\
\end{array}$ & 14,143 & 11,314 & 56,572 & $\begin{array}{r}134,64 \\
1 \\
\end{array}$ & $\begin{array}{r}135,77 \\
2 \\
\end{array}$ & $\begin{array}{r}5091 \\
4 \\
\end{array}$ & 5657 & $\begin{array}{r}4525 \\
7 \\
\end{array}$ & 62229 \\
\hline Ishielu. & 30 & 193,666 & 5.423 & $\begin{array}{r}199,08 \\
9 \\
\end{array}$ & 9.954 & 7,964 & 39,818 & 94,766 & 95,563 & $\begin{array}{r}3583 \\
6 \\
\end{array}$ & 3982 & $\begin{array}{r}3185 \\
4 \\
\end{array}$ & 43800 \\
\hline Ivo & 18 & 155,036 & 4,341 & $\begin{array}{r}159,37 \\
7 \\
\end{array}$ & 7,969 & 6,375 & 31,875 & 75,863 & 76,501 & $\begin{array}{r}2868 \\
8 \\
\end{array}$ & 3188 & $\begin{array}{r}2550 \\
0\end{array}$ & 35063 \\
\hline Izxi & 25 & 300.115 & 8.403 & $\begin{array}{r}308,51 \\
8\end{array}$ & 15.426 & 12.341 & 61,704 & $\begin{array}{r}146,85 \\
5\end{array}$ & $\begin{array}{r}148,08 \\
9\end{array}$ & $\begin{array}{r}5553 \\
3\end{array}$ & 6170 & $\begin{array}{r}4936 \\
3\end{array}$ & 67874 \\
\hline Ohaozara & 25 & 190,560 & 5.336 & $\begin{array}{r}195,89 \\
6 \\
\end{array}$ & 9,795 & 7,836 & 39,179 & 93,246 & 94,030 & $\begin{array}{r}3526 \\
1 \\
\end{array}$ & 3918 & $\begin{array}{r}3134 \\
3 \\
\end{array}$ & 43097 \\
\hline Ohauksru & 40 & 251,733 & 7,049 & $\begin{array}{r}258,78 \\
2 \\
\end{array}$ & 12.939 & 10,351 & 51,736 & $\begin{array}{r}123,18 \\
0 \\
\end{array}$ & $\begin{array}{r}124,21 \\
5 \\
\end{array}$ & $\begin{array}{r}4658 \\
1 \\
\end{array}$ & 5176 & $\begin{array}{r}4140 \\
5 \\
\end{array}$ & 56932 \\
\hline Onicha & 25 & 303,648 & 8.502 & $\begin{array}{r}312,15 \\
0 \\
\end{array}$ & 15,608 & 12.486 & 62,430 & $\begin{array}{r}148,58 \\
3 \\
\end{array}$ & $\begin{array}{r}149,83 \\
2 \\
\end{array}$ & $\begin{array}{r}5618 \\
7 \\
\end{array}$ & 6243 & $\begin{array}{r}4994 \\
4 \\
\end{array}$ & 68673 \\
\hline & 296 & $2,710,845$ & $\begin{array}{r}78,02 \\
9 \\
\end{array}$ & $\begin{array}{r}2,864,7 \\
76\end{array}$ & $\begin{array}{r}143,23 \\
9 \\
\end{array}$ & $\begin{array}{r}114,59 \\
1\end{array}$ & $\begin{array}{r}572,95 \\
5 \\
\end{array}$ & $\begin{array}{r}1,363,6 \\
33 \\
\end{array}$ & $\begin{array}{r}1,375,0 \\
92 \\
\end{array}$ & $\begin{array}{r}5156 \\
60 \\
\end{array}$ & $\begin{array}{r}5729 \\
6 \\
\end{array}$ & $\begin{array}{r}4583 \\
64 \\
\end{array}$ & $\begin{array}{r}63025 \\
1\end{array}$ \\
\hline
\end{tabular}

Figure 1. 2016 EBONYI STATE POPULATION PROJECTED FROM 2006

Source: Ebonyi State Ministry of Health, 2016.

\subsection{Sample and Sampling Techniques}

A multi-stage sampling procedure was used to select a sample of 400 out-patients that attended the State-owned General Hospitals in the thirteen LGAs. The first stage involved clustering and random sampling of the zones namely: Abakaliki, Afikpo, and Onueke education zones; the second stage involved the determination of sample size for each zone identified in the first stage: Abakaliki education (131), Onueke education (119), and Afikpo (150), to ensure equal representation of all the zones in the State. In the third stage, two General hospitals were selected per zone giving rise to a total of 6 hospitals. Lastly, the participants were selected using a simple random technique of balloting without replacement.

\subsection{Ethical approval}

Ethical approval was obtained from the Review Board of the Department of Human Kinetics and Health Education, 
Faculty of Education, Ebonyi State University (EBSU/FOE/KHE/018). Informed consent was also obtained from all the respondents for the study.

\subsection{Instrument for Data Collection}

The instrument for data collection was a self-administered questionnaire titled: Patient Satisfaction with quality of Care. The questionnaire has 10-item consisting of 2 sections: Sections 1 has 4 items on the socio-demographic characteristics of the respondents based on age, educational level, marital status, household income, and clinics attended while; 2 is made up of 6 items meant to elicit information on waiting time, communication, empathy, competency, cost, and access. The items were measured on a four-point Likert scale through 1 to 4 which indicated: 1-very dissatisfied; 2-dissatisfied; 3-satisfied; and 4-very satisfied. The reliability of the instrument was established using data collected from 30 patients in a general hospital within the study setting not included in the sample. The internal consistency of the instrument was computed using Cronbach alpha. The process yielded an overall reliability of the coefficient of 0.795 which was deemed good enough for this study. This was utilized by Otani, Waterman, Faulkner, Boslaugh, \& Dunagan, (2010).

\subsection{Method of Data Analysis}

The returned copies of the questionnaires were cross-checked for completeness of responses. Of 400 copies distributed, 396 were retrieved representing a 99\% return rate, thereafter, data were analyzed using mean $(x)$ score, standard deviation, t-test and Analysis of Variance (ANOVA).

A criterion mean $(x)$ of 2.50 was set for the study which was derived by adding up the scale values and dividing the sum by the number of scale options. Thus: $4+3+2+1=10 / 4+2.50$. A criterion means of 2.50 and above was adjudged to be highly satisfied while below 2.50 was considered 'lowly satisfied'. Also, a t-test and ANOVA were used to test hypotheses at $\mathrm{p} \leq 0.05$ level of significance (Uzoagulu, 2011).

\section{Results}

\subsection{Sociodemographic Characteristics of Respondents}

In this study, respondents ages were 18-39 years $233(58.8 \%)$, 40-60 years 120(30.3\%), and 61 years and above $43(10.9 \%)$. For the educational level of respondents, illiterates were [139 (35.1\%) primary school leavers; $86(21.7 \%)$, secondary school education; $86(21.7 \%)$ while $(71.9 \%)$ have attended tertiary institutions. On marital status, $(55.8 \%)$ were married, $25.3 \%$ single, $16.4 \%$ widowed, and $2.5 \%$ were divorced. Majority of patients $(170(42.9 \%)$ belonged to the lowest income class ( $<\mathrm{N} \mathrm{18,000} \mathrm{per} \mathrm{month).} 112(28.3 \%)$ earn N40,000 to N 79000; 13(3.3\%) earned $\mathrm{N} 60,000$ to $\mathrm{N} 79000$ monthly while 21(5.3\%) earned N80,000 and above. Most of the respondents, 277 (69.9\%) attended general out-patient clinic and fewer 24 (6.1\%) attended dental clinic (Table 1). 
Table 1. Respondents' Socio-demographic Characteristics and Clinics Attended

\begin{tabular}{|c|c|c|}
\hline Characteristics & Frequency & Percent (\%) \\
\hline \multicolumn{3}{|l|}{ Age (Years) } \\
\hline $18-39$ & 233 & 58.8 \\
\hline $40-60$ & 120 & 30.3 \\
\hline 61 and above & 43 & 10.9 \\
\hline \multicolumn{3}{|l|}{ Marital Status } \\
\hline Single & 100 & 25.3 \\
\hline Married & 221 & 55.8 \\
\hline Divorced & 10 & 2.5 \\
\hline Widowed & 65 & 16.4 \\
\hline \multicolumn{3}{|l|}{ Educational Status } \\
\hline None & 86 & 21.7 \\
\hline Primary & 100 & 25.3 \\
\hline Secondary & 139 & 35.1 \\
\hline Tertiary & 71 & 17.9 \\
\hline \multicolumn{3}{|l|}{ Income Level (N) } \\
\hline Below 18,000 & 170 & 42.9 \\
\hline $18,000-39,000$ & 112 & 28.3 \\
\hline $40,000-59,000$ & 80 & 20.2 \\
\hline $60,000-79,000$ & 13 & 3.3 \\
\hline 80,000 and above & 21 & 5.3 \\
\hline \multicolumn{3}{|l|}{ Clinics Attended } \\
\hline Eye Clinic & 32 & 8.1 \\
\hline Dental Clinic & 24 & 6.1 \\
\hline General Out-patient Clinic & 277 & 69.9 \\
\hline Infant Welfare Clinic & 37 & 9.3 \\
\hline Antenatal Care & 26 & 6.6 \\
\hline Total & 396 & $100 \%$ \\
\hline
\end{tabular}

\subsection{Patients'Satisfaction Based on Socio-Demographic Characteristics}

Respondents within the age group of 40-60 years got the highest mean scores in waiting time $(\bar{X}=2.95)$, communication $(\bar{X}=3.13)$, empathy $(\bar{X}=3.20)$, competency $(\bar{X}=3.10)$, cost $(\bar{X}=2.79)$ and access $(\bar{X}=2.60)$ with the grand mean of 2.96. Based on education, the primary group was the most satisfied group with the highest mean score of 2.97. Also, married respondents were satisfied most in waiting time $(\bar{X}=2.87)$ and access $(\bar{X}=$ $2.63)$, thus most satisfied with quality of care followed by widowed respondents with the mean score in waiting time $(\bar{X}=2.84)$ and access $(\bar{X}=2.61)$. Single respondents are the least satisfied with the quality of care with a grand mean of 2.77. For income level respondents who earned N18, 000 to N39000 were satisfied most in waiting time ( $\bar{X}=2.95)$, communication ( $\bar{X}=3.19)$, empathy $(\bar{X}=3.21)$, competency $(\bar{X}=3.12)$ and access $(\bar{X}=2.57)$ whereas N 40,000 to N59, 000 respondents were most satisfied with the cost of service ( $\bar{x}=2.88)$. Respondent, earning N80, 000 and above got the highest mean score in access $(\bar{X}=2.90)$. (Table 2) 
Table 2. Patients' Satisfaction Score based on socio-demographic characteristics

\begin{tabular}{|c|c|c|c|c|c|c|c|c|}
\hline \multirow[b]{2}{*}{ Characteristics } & \multirow[b]{2}{*}{$\mathbf{N}$} & \multicolumn{7}{|l|}{ Mean } \\
\hline & & $\begin{array}{l}\text { Waiting } \\
\text { Time } \\
\bar{X}\end{array}$ & $\begin{array}{l}\text { Communication } \\
\bar{x}\end{array}$ & $\begin{array}{l}\text { Empathy } \\
x\end{array}$ & $\begin{array}{l}\text { Competency } \\
\bar{x}\end{array}$ & Cost & $\begin{array}{l}\text { Access } \\
\bar{X}\end{array}$ & $\begin{array}{l}\text { Grand } \\
\text { Mean }\end{array}$ \\
\hline \multicolumn{9}{|l|}{ Age (Years) } \\
\hline 18-39 & 233 & 2.85 & 3.07 & 3.08 & 3.06 & 2.72 & 2.59 & 2.89 \\
\hline $40-60$ & 120 & 2.85 & 3.13 & 3.20 & 3.10 & 2.76 & 2.60 & $2.96^{*}$ \\
\hline $61 \&$ above & 43 & 2.72 & 2.84 & 3.06 & 3.05 & 2.63 & 2.43 & 2.79 \\
\hline \multicolumn{9}{|l|}{ Educational Level } \\
\hline None & 86 & 2.49 & 2.75 & 2.88 & 2.96 & 2.54 & 2.30 & 2.65 \\
\hline Primary Education & 100 & 2.94 & 3.13 & 3.17 & 3.11 & 2.81 & 2.70 & $2.97^{*}$ \\
\hline $\begin{array}{l}\text { Secondary } \\
\text { Education }\end{array}$ & 139 & 2.92 & 3.12 & 3.18 & 3.04 & 2.78 & 2.67 & 2.95 \\
\hline Tertiary Education & 71 & 2.94 & 3.23 & 3.22 & 3.19 & 2.71 & 2.54 & $2.97^{*}$ \\
\hline \multicolumn{9}{|l|}{ Marital Status } \\
\hline Single & 100 & 2.76 & 2.95 & 2.98 & 2.89 & 2.55 & 2.47 & 2.77 \\
\hline Married & 221 & 2.87 & 3.08 & 3.14 & 3.11 & 2.72 & 2.63 & $3.09^{*}$ \\
\hline Widowed & 65 & 2.84 & 3.13 & 3.23 & 3.23 & 2.99 & 2.61 & 3.01 \\
\hline Divorced & 10 & 2.78 & 3.28 & 3.24 & 3.03 & 2.80 & 2.07 & 2.87 \\
\hline \multicolumn{9}{|l|}{ Income Level (N) } \\
\hline$<18,000$ & 170 & 2.70 & 2.94 & 3.00 & 3.02 & 2.73 & 2.56 & 2.83 \\
\hline $18,000-39,000$ & 112 & 2.95 & 3.19 & 3.21 & 3.12 & 2.63 & 2.57 & 2.95 \\
\hline $40,000-59,000$ & 80 & 2.94 & 3.15 & 3.20 & 3.11 & 2.88 & 2.55 & $2.97^{*}$ \\
\hline $60,000-79,000$ & 13 & 2.77 & 3.02 & 3.32 & 3.03 & 2.38 & 2.38 & 2.82 \\
\hline$>80,000$ & 21 & 2.93 & 3.06 & 3.15 & 3.08 & 2.71 & 2.90 & $2.97^{*}$ \\
\hline
\end{tabular}

\subsection{Analysis of Variance (ANOVA) on Patients'Satisfaction Based on Socio-demographics}

Table 3 showed the analysis of variance (ANOVA) among respondents of different ages in their satisfaction with the quality of care in the state. There was no significant difference in patients' satisfaction with waiting time, empathy, competency, cost of service, and access among the respondents of different ages $(p>0.05)$; while on communication, there is a significant difference in patients' satisfaction $(p<0.05)$ with health providers. Thus, based on age, the null hypothesis that there is no significant difference in patients' satisfaction with waiting time, empathy, competency, cost of service and access were accepted while the null hypothesis that there is no significant difference in patients' satisfaction with communication with health workers was rejected. Based on educational qualifications, there is a significant difference in patients' satisfaction with waiting time, communication, empathy of health workers among respondents of different level of educational qualification ( $\mathrm{p}<$ $0.05)$, but there is no significant difference in their satisfaction with competency access, and cost of the service ( $p>$ 0.05). Thus based on educational qualifications, the null hypothesis that there is no significant difference in patients' satisfaction with competency access and cost of service is accepted and the null hypothesis that there is no significant difference in patient satisfaction with waiting time, communication, empathy, and access is rejected.

The analysis indicates that there is no significant difference among respondents of different marital statuses in their satisfaction with waiting time, communication, empathy, and access to facilities $(p>0.05)$. On competency, and cost of services, there is a significant difference among respondents based on marital status $(p<0.05)$. Thus the null hypothesis that there is no significant difference among respondents of different marital statuses on satisfaction with waiting time, communication, empath, and access will be accepted and the null hypothesis that there is no significant difference in patient satisfaction with competency, and cost of service will be rejected. 
The analysis indicates that there is no significant difference among different levels of income on their satisfaction with waiting time, communication, competency, cost of service, access to facilities, and empathy $(p<0.05)$. Therefore, the null hypothesis that there is no significant difference in patients' satisfaction with waiting time, communication competency, cost of service, access to facilities, and empathy, based on income levels of the respondents was accepted.

Table 3. Summary of Analysis of Variance (ANOVA) on Patients' Satisfaction Based on Socio-demographics

\begin{tabular}{|c|c|c|c|c|c|c|c|}
\hline Source of Variance & $\begin{array}{l}\text { Sum } \\
\text { Squares }\end{array}$ & of Df & $\begin{array}{l}\text { Mean } \\
\text { Square }\end{array}$ & of & F-cal & p-value & Dec. \\
\hline \multicolumn{8}{|l|}{ Age } \\
\hline \multicolumn{8}{|l|}{ Waiting Time } \\
\hline Between Groups & .628 & 2 & & & & & \\
\hline Within groups & 179.537 & 393 & 0.314 & & \multirow{2}{*}{0.687} & \multirow{2}{*}{0.503} & \multirow{2}{*}{ NS } \\
\hline Total & 180.166 & 395 & 0.457 & & & & \\
\hline \multicolumn{8}{|l|}{ Communication } \\
\hline Between Groups & 2.581 & 2 & & & & & \\
\hline Within groups & 153.029 & 393 & 1.290 & & \multirow{2}{*}{3.314} & \multirow{2}{*}{$0.037 *$} & \multirow{2}{*}{$\mathrm{S}$} \\
\hline Total & 155.609 & 395 & 0.389 & & & & \\
\hline \multicolumn{8}{|l|}{ Empathy } \\
\hline Between Groups & 1.307 & 2 & & & & & \\
\hline Within groups & 127.816 & 393 & 0.654 & & \multirow{2}{*}{2.010} & \multirow{2}{*}{0.135} & \multirow{2}{*}{ NS } \\
\hline Total & 129.123 & 395 & 0.325 & & & & \\
\hline \multicolumn{8}{|l|}{ Competency } \\
\hline Between Groups & 0.177 & 2 & & & & & \\
\hline Within groups & 156.759 & 393 & 0.089 & & \multirow{2}{*}{0.222} & \multirow{2}{*}{0.801} & \multirow{2}{*}{ NS } \\
\hline Total & 156.937 & 395 & 0.399 & & & & \\
\hline \multicolumn{8}{|l|}{ Cost } \\
\hline Between Groups & 0.564 & 2 & & & & & \\
\hline Within groups & 226.065 & 393 & 0.282 & & \multirow{2}{*}{0.490} & \multirow{2}{*}{0.613} & \multirow{2}{*}{ NS } \\
\hline Total & 226.629 & 395 & 0.575 & & & & \\
\hline \multicolumn{8}{|c|}{ Access to facilities in the Hospital } \\
\hline Between Groups & 1.065 & 2 & & & & & \\
\hline Within groups & 318.700 & 393 & 0.533 & & \multirow{2}{*}{0.657} & \multirow{2}{*}{0.519} & \multirow{2}{*}{ NS } \\
\hline Total & 319.765 & 395 & 0.811 & & & & \\
\hline \multicolumn{8}{|l|}{ Educational level } \\
\hline \multicolumn{8}{|l|}{ Waiting Time } \\
\hline Between Groups & 13.228 & 3 & & & & & \\
\hline Within groups & 166.938 & 392 & 4.409 & & \multirow{2}{*}{10.354} & & \\
\hline Total & 180.166 & 395 & 4.26 & & & 0.00 & $\mathrm{~S}$ \\
\hline Communication & & & & & & & \\
\hline Between Groups & 11.239 & 3 & 3.746 & & & & \\
\hline Within groups & 144.370 & 392 & 3.68 & & 10172 & $0 \cap 0$ * & $\mathrm{S}$ \\
\hline Total & 155.609 & 395 & & & 10.172 & 0.00 & 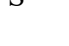 \\
\hline
\end{tabular}




\begin{tabular}{|c|c|c|c|c|c|c|}
\hline \multicolumn{7}{|l|}{ Empathy } \\
\hline Between Groups & 6.337 & 3 & & \multirow{3}{*}{6.744} & \multirow{3}{*}{$0.00^{*}$} & \multirow{3}{*}{ S } \\
\hline Within groups & 122.786 & 392 & 2.112 & & & \\
\hline Total & 129.123 & 395 & 3.68 & & & \\
\hline \multicolumn{7}{|l|}{ Competency } \\
\hline Between Groups & 2.519 & 2 & & \multirow{3}{*}{2.132} & \multirow{3}{*}{0.96} & \multirow{3}{*}{ NS } \\
\hline Within groups & 154.418 & 392 & 8.40 & & & \\
\hline Total & 156.937 & 395 & 3.94 & & & \\
\hline \multicolumn{7}{|l|}{ Cost } \\
\hline Between Groups & 4.124 & 3 & & \multirow{3}{*}{2.422} & \multirow{3}{*}{0.66} & \multirow{3}{*}{ NS } \\
\hline Within groups & 222.505 & 392 & 1.375 & & & \\
\hline Total & 226.629 & 395 & 5.68 & & & \\
\hline \multicolumn{7}{|c|}{ Access to facilities in the Hospital } \\
\hline \multirow{3}{*}{$\begin{array}{l}\text { Between Groups } \\
\text { Within groups } \\
\text { Total }\end{array}$} & & & \multirow{3}{*}{$\begin{array}{l}3.146 \\
7.92\end{array}$} & \multirow{3}{*}{3.974} & \multirow{3}{*}{0.08} & \multirow{3}{*}{ NS } \\
\hline & 310230 & 200 & & & & \\
\hline & 310.328 & 392 & & & & \\
\hline \multicolumn{7}{|l|}{ Marital status } \\
\hline \multicolumn{7}{|l|}{ Waiting Time } \\
\hline Between Groups & 8.04 & 3 & 2.68 & \multirow{3}{*}{5.86} & \multirow{3}{*}{6.25} & \multirow{3}{*}{ NS } \\
\hline Within groups & 179.362 & 392 & 4.58 & & & \\
\hline Total & 180.166 & 395 & & & & \\
\hline \multicolumn{7}{|l|}{ Communication } \\
\hline Between Groups & 2.176 & 3 & 7.25 & \multirow{3}{*}{1.853} & & \\
\hline Within groups & 153.433 & 392 & 3.91 & & 127 & NSC \\
\hline Total & 155.609 & 395 & & & 1.01 & IV \\
\hline Empathy & & & & & & \\
\hline Between Groups & 2.926 & 3 & 9.75 & & & \\
\hline Within groups & 126.198 & 392 & 3.22 & 3020 & 020 & NS \\
\hline Total & 129.123 & 395 & & 3.029 & 0.29 & NS \\
\hline Competency & & & & & & \\
\hline Between Groups & 5.228 & 3 & & & & \\
\hline Within groups & 151.709 & 392 & 1.743 & 4503 & $004 *$ & $\mathrm{~S}$ \\
\hline Total & 156.937 & 395 & 3.87 & 4.505 & 0.04 & $\mathrm{~s}$ \\
\hline Cost & & & & & & \\
\hline Between Groups & 7.794 & 3 & 2.598 & & & \\
\hline Within groups & 218.835 & 392 & 5.58 & 4654 & $003 *$ & $\mathrm{~S}$ \\
\hline Total & 226.629 & 395 & & 4.034 & $0.03^{\circ}$ & $\mathrm{S}$ \\
\hline Access to faciliti & & & & & & \\
\hline Between Groups & 4.366 & 3 & 1455 & & & \\
\hline Within groups & 315.399 & 392 & 805 & 1809 & 145 & NS \\
\hline Total & 319.765 & 395 & 0.03 & 1.009 & $1.4 \mathrm{~J}$ & No \\
\hline
\end{tabular}




\begin{tabular}{|c|c|c|c|c|c|c|}
\hline Income & & & & & & \\
\hline Waiting Time & & & & & & \\
\hline Between Groups & 5.498 & 4 & & \multirow{3}{*}{3.077} & \multirow{3}{*}{0.16} & \multirow{3}{*}{ NS } \\
\hline Within groups & 174.668 & 391 & 1.374 & & & \\
\hline Total & 180.166 & 395 & 4.47 & & & \\
\hline \multicolumn{7}{|l|}{ Communication } \\
\hline Between Groups & 4.889 & 4 & & \multirow{3}{*}{3.171} & \multirow{3}{*}{0.09} & \\
\hline Within groups & 150.720 & 391 & 1.222 & & & \multirow{2}{*}{ NS } \\
\hline Total & 155.609 & 395 & 3.85 & & & \\
\hline \multicolumn{7}{|l|}{ Empathy } \\
\hline Between Groups & 4.417 & 4 & & \multirow{3}{*}{3.463} & & \\
\hline Within groups & 124.706 & 391 & 1.104 & & \multirow{2}{*}{6.70} & \multirow{2}{*}{ NS } \\
\hline Total & 129.123 & 395 & 3.19 & & & \\
\hline \multicolumn{7}{|l|}{ Competency } \\
\hline Between Groups & 9.42 & 4 & & \multirow{3}{*}{5.90} & & \\
\hline Within groups & 155.995 & 391 & 2.35 & & \multirow{2}{*}{0.97} & \multirow{2}{*}{ NS } \\
\hline Total & 156.937 & 395 & 3.99 & & & \\
\hline \multicolumn{7}{|l|}{ Cost } \\
\hline Between Groups & 497 & 3 & & & & \\
\hline Within groups & 222.132 & 392 & 1.124 & \multirow{2}{*}{1.979} & \multirow{2}{*}{4.78} & \multirow{2}{*}{ NS } \\
\hline Total & 226.629 & 395 & 5.68 & & & \\
\hline \multicolumn{7}{|c|}{ Access to facilities in the Hospital } \\
\hline Between Groups & 2.839 & 4 & & & & \\
\hline Within groups & 316.926 & 391 & 7.10 & \multirow{2}{*}{8.76} & \multirow{2}{*}{4.78} & \multirow{2}{*}{ NS } \\
\hline Total & 319.765 & 395 & 8.11 & & & \\
\hline
\end{tabular}

$\mathrm{S}=$ Significant, NS= Not significant.

\section{Discussion}

\subsection{Association of Patients' Satisfaction and Socio-Demographic Characteristics}

Regarding age, the study revealed that there was no association between patients' satisfaction and age, while older age group (40-60years) respondents were more satisfied than the younger ones $(\bar{x}=2.96, \mathrm{p}>0.05)$. These assertions were also expressed by Saeed, Mohammed, Magzoub, \& Al-Doghaither, (2001); Djordjevic \&

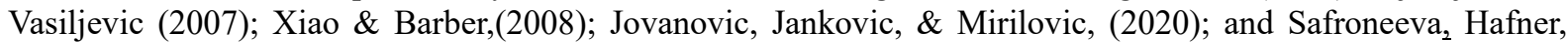
Kuehni, Zwahlen, Trelle, Biedermann, et al., (2020) who opined that older patients were more satisfied. Also, Bleich, Ozaltin and Murray, (2009); Afzal, Khan, Rizvi, and Hussain (2011); El-Nasser and Mohammed (2013); Afzal, Rizvi, Azal, Rajput, Khan and Tariq (2014); Othman, Hussein, Alfaisal and Wasfy, (2015); Gustafsson, Martinsson, Walivaara, Vikman, and Slegan (2016); Chen, Li, \& Zhang, (2016); and Xesfingi and Vozikis, (2016); reported the same. While in other studies, no significant difference was reported between age and satisfaction (Ashrafun \& Uddin, 2011; Abadelhatez, Alqurashi, Alziyardi, Kuwair, Shohki, \& Morgrabi, 2012; Vidhya \& Rajakumar, 2014; Garba, Gadanya, Iliyasu, \& Gajida, 2018) Contrastingly, studies of Liu and Fang, (2019); and Karaca, and Durna, (2019) revealed that Patients who were 18-35 years old, were more satisfied with care while (Cosma, Bota, Fleseriu, Morgan, Valeanu, \& Cosma, 2020) found a statistically significant relationship between patients' satisfaction and age.

The present study showed that more educated patients were significantly more satisfied $(\bar{X}=2.97, \mathrm{p}<0.05)$ than the illiterate ones. The finding was consistent with many other studies by Xlao \& Barber, (2008); Assefa, Mosse, \& Hailemichael, (2011); Bener \& Ghuloum, (2013); Abodunrin, Adeomi \& Adeoye (2014); Rahman, Ngadan, \& 
Arif (2016); and Iwu, Duru, Uwakwe, Diwe, Merenu, Chineke et al (2017); and Karaca, and Durna, (2019). In the same vein Kassaw, Tesfaye, Girma, \& Agenagnew, (2020) reported that the overall percentage of patient satisfaction was having secondary and above educational status, which was significantly associated with patient satisfaction. In contrast to that, lower education respondents have shown higher satisfaction in the findings of Bleich, et al., (2009), Afzal et al. (2014), Othman, et al., (2015); Okeke, Bassey, Oduwole, and Adindu, (2019); and Jovanovic, et al (2020). Also, Ashrafun and Uddin, (2011) reported that university-educated patients were less satisfied while Sharifi, Baraz, Mohammadi, Ramezani, and Vardanjani, (2012); and Sharew, Bizuneh, Assefa, and Habtewold, (2018) reported more satisfaction among low educated people. Further revelation from other studies showed that there was no association between education and overall satisfaction (Abadelhatez et al., 2012; Vidhya \& Rajakumar, 2014; Garba et al., 2018; Devi, Laishram, Singh, \& Devi, 2020).

Marital status was shown to be an important factor in patients' satisfaction with the healthcare system. The present study showed that married patients were most satisfied though not significant $(\bar{X}=3.09, \mathrm{p}<0.05)$. Which is in agreement with findings of Sharifi, et al., (2012); Odetola (2015), Djordjevic and Vasiljevic, (2017); Karaca and Durna, (2019); and Okeke, et al., (2019); who reported more satisfaction among married people. While Garba et al., (2018) and Devi, et al (2020) found marital status not significantly associated with satisfaction status. In contrast, the highest satisfaction was seen among widows in the studies of Afzal, et al., (2011) and Afzal, et al. (2015); while Garba, Gadanya, Iliyasu, and Gajida, (2015); Chen, Li and Zhang (2016); Iwu, Duru, Uwakwe, Diwe, Merenu, Chineke, et al., (2017); and Oluwole, Osibogun, Adegoke, Adejimi, Adewole \& Osibogun (2019), found a statistically significant relationship between patients' satisfaction and marital status.

Regarding income, this study showed a higher satisfaction among those with higher income levels (N40,000 N59,000 and $>80,000)$ which is not statistically significant $(\bar{x}=2.97, \mathrm{p}>0.05)$ (Table 2,3). This is in line with the findings of Saeed, Mohammed, Magzous, et al., (2001) and Liu and Fang (2019) who reported that higher-income respondents have high more satisfaction while Devi, Laishram, Singh, and Devi (2020) found no significant difference between the level of satisfaction with income. In contrast, Ashrafun and Uddin (2011); and Afzal, et al., (2014) reported that respondents with a higher level of income had a lower level of satisfaction. Chen, Li, and Zhang (2016) stated there was no significant association between patients' satisfaction and family income. Contrastingly, Myburgh, Solanki, Smith, and Lalloo, (2005) stated that socioeconomic status were significant predictors of levels of satisfaction with the services of health care providers. Supported by Cosma, et al (2020) who found a statistically significant relationship between patients' satisfaction and income. Other reports revealed that lower-income respondents were more satisfied and was significantly associated with level of satisfaction (Afzal et al., 2011; Vidhya \& Rajakumar, 2014; Okeke et al., 2019; Jovanovic, et al., 2020)

\section{Conclusions}

Conclusively the study revealed that patients of older age, more educated, middle-class income earners, married, were more satisfied with the quality of care. However, only the level of education was significant in this study. Efforts should be made by Health workers to ensure that all patients are satisfied irrespective of their demographic characteristics.

\section{Competing Interests Statement}

The authors declare that there are no competing or potential conflicts of interest.

\section{References}

Abadelhatez, A. M., Alqurashi, L., Alziyardi, R., Kuwair, A., Shohki, M., \& Morgrabi, H. (2012). Analysis of factors affecting the satisfaction level of patients toward food services at general hospital in Makkah, Saudi Arabia. American Journal of Medicine and Medical Sciences, 2(6), 123-130. https://doi.org/10.5923/j.ajmms.20120206.03

Abodunrin, O. L., Adeomi, A., \& Adeoye, A. (2014). Clients' satisfaction with quality of healthcare received: Study among mothers attending infant welfare clinics in a semi-urban community in South-western Nigeria. Sky Journal of Medicine and Medical Sciences, 2(7), 45-51.

Afzal, M., Khan, A., Rizvi, F., \& Hussain, A. (2011). Patients Satisfaction Levels in Out Patient Department of a Teaching Hospital. Journal of Islamabad Medical \& Dental College (JIMDC), 1211(1), 26-29. 26.

Afzal, M., Rizvi, F., Azad, A. H., Rajput, A. M., Khan, A., \& Tariq, N. (2014). Effect of demographic characteristics on patient satisfaction with health care. Postgraduate medical institute, 28, 154-160.

Alrubaiee, L., \& Alkaa'ida, F. (2011). The Mediating Effect of Patients' Satisfaction in the Patients' Perception of Health Quality - Patient Trust Relationship. International Journal of Marketing Studies, 3(1), 103-121. 
https://doi.org/10.5539/ijms.v3n1p103

Amole, B. B., Oyetoye, E. O., \& Kuye, O. L., (2015). Determinants of patient satisfaction on Service Quality Dimensions in the Nigeria Teaching Hospitals. JEL Classification, 110, HS.

Anyika, E. N. (2014). Challenges of implementing sustainable health care delivery in Nigeria under environmental uncertainty. Journal of Hospital Administration, 3(6). http://dx.doi.org/10.5430/jha.v3n6p113

Ashrafun, L., \& Uddin, M. J. (2011). Factors Determining Inpatient Satisfaction with Hospital Care in Bangladesh. Asian Social Science, 7(6). https://doi.org/ 10.5539/ass.v7n6915

Assefa, F., Mosse, A., \& Hailemichael, Y. (2011). Assessment of clients' satisfaction with health service deliveries at jimma university specialized hospital. Ethiopian journal of health sciences, 21(2), 101-109. https://doi.org/10.4314/ejhs.v21i2.69050

Bener, A., \& Ghuloum, S. (2013). Gender difference on patients' satisfaction and expectation towards mental health care. Nigerian journal of clinical practice, 16(3), 285-291. https://doi.org/10.4103/1119-3077.113448

Bleiech, S. N., Ozaltin, E., \& Murrey, C. J. L. (2009). How does satisfaction with the health-care system related to patient experience? Bulletin of World Health Organization, 87, 271-278. https://doi.org/10.247/BLT.07.050401

Chandra, S., Ward, P., \& Mohammadnezhad, M. (2019). Factors Associated with Patient Satisfaction in Outpatient Department of Suva Sub-Divisional Health Center, Fiji, 2018: A Mixed Method Study. Frontiers in Public Health, 7, 183. https://doi.org/10.3389/fpubh.2019.00183

Chen, H., Li, M., Wang, J., Xue, C., Ding, T., Nong, X., Liu, Y., \& Zhang, L. (2016). Factors influencing inpatients' satisfaction with hospitalization service in public hospitals in Shanghai, People's Republic of China. Patient preference and adherence, 10, 469-477. https://doi.org/10.2147/PPA.S98095

Cosma, S.A., Bota, M., Fleseriu, C., Morgovan, C., Valeanu, M., \& Cosma, D., (2020) Measuring Patients' Perception and Satisfaction with the Romanian Healthcare System. Sustainability, 12, 1612. https://doi.org/10.3390/su12041612

Devi, Y. N., Laishram, J., Singh, T. G., \& Devi, H. S. (2020). Patients' satisfaction study in the out-patient departments of the two tertiary government hospitals in Manipur. IOSR Journal of Dental and Medical Sciences (IOSR-JDMS), 19(2), Ser.4, 05-09. https://doi.org/10.9790/0853-1902040509

Djordjevic, I. M., \& Vasiljevic, D. (2017). The Effect of Sociodemographic Factors On the Patient Satisfaction with Health Care System. Serbian Journal of Experimental and Clinical Research, 1-1. https://doi.org/doi:10.1515/SJECR-2017-0042

Ebonyi State Ministry of Health. Malaria Elimination Programme. (2016). 2017 Annual Operational Plan Development Workshop, Abakaliki, Nigeria. November, 2016.

El-Nasser, G. A., \& Mohammed, N. (2013). Patient satisfaction with preoperative care and its relationship with patients' characteristics. The Medical Journal of Cairo university, 81(2), 1-10

Garba, M. R., Gadanya, M. A., Iliyasu, Z., \& Gajida, A. U. (2018). Comparative study of patients' satisfaction between national health insurance scheme-insured and un-insured patients attending a Northern Nigerian tertiary hospital. Nigerian Journal of Basic and Clinical Sciences, 15, 118-26. https://doi.org/10.4103/njbcs.njbcs_48_16

Gustafsson, S., Martinsson, J., Wälivaara, B. M., Vikman, I., \& Sävenstedt, S. (2016). Influence of self-care advice on patient satisfaction and healthcare utilization. Journal of advanced nursing, 72(8), 1789-1799. https://doi.org/10.1111/jan.12950

Iwu, A. C., Duru, C. B., Uwakwe, K. A., Diwe, K. C., Merenu, I. A., Chineke, H. N. et al. (2017). Patients' Perception and Satisfaction with the Quality of HIV Care Services and Its Associated Socio-demographic Determinants in a Tertiary Care Hospital. British Journal of Medicine and Medical Research, 20(4), 1-14.

Jovanovic, D., Jankovic, J., \& Mirilovic, N. (2020). Socio-demographic inequalities in satisfaction with primary health care and utilization of chosen doctors' services: a cross-sectional study. South Eastern European Journal of Public Health (SEEJPH). https://doi.org/10.4119/seejph-3311.

Karaca, A., \& Durna, Z. (2019). Patient satisfaction with the quality of nursing care. Nursing open, 6(2), 535-545. https://doi.org/10.1002/nop2.237

Kassaw, C., Tesfaye, E., Girma, S., \& Agenagnew, L. (2020). Perceived Patient Satisfaction and Associated 
Factors among Psychiatric Patients Who Attend Their Treatment at Outpatient Psychiatry Clinic, Jimma University Medical Center, Southwest Ethiopia, Jimm. 2019. Hindawi Psychiatry Journal, 6153234, 1-10. https://doi.org/10.1155/2020/6153234

Liu, L., \& Fang, J. (2019). Study On Potential Factors of Patient Satisfaction: Based On Exploratory Factor Analysis. Patient Preference and Adherence, 13, 1983-1994. https://doi.org/10.2147/PPA.S228073

Megbelayin, E. O., Babalola, Y. O., Kurawa, M., Opubiri, I., \& Okonkwo, S. N. (2014). How satisfied are patients attending a Nigeria eye clinic in university of Calabar Teaching Hospital. International Archives of integrated Medicine, 1(4), 1-9.

Myburgh, N. G., Solanki, G. C., Smith, M. J., \& Lalloo, R. (2005). Patient satisfaction with health care providers in South Africa: the influences of race and socioeconomic status. International journal for quality in health care: journal of the International Society for Quality in Health Care, 17(6), 473-477. https://doi.org/10.1093/intqhe/mzi062

Odetola, T. D. (2015). Health care utilization among rural women of child-bearing age: a Nigerian experience. The Pan African medical journal, 20, 151. https://doi.org/10.11604/pamj.2015.20.151.5845

Okeke, H. C., Bassey, P., Oduwole, O. A., \& Adindu, A. (2019). Client characteristics and satisfaction with the quality of primary health-care services in Calabar, Nigeria. Calabar Journal of Health Science, 3(1), 1-8.

Oluwole, E. O., Osibogun, O., Adegoke, O., Adejimi, A. A., Adewole, A. M., \& Osibogun, A. (2019). Medication adherence and patient satisfaction among hypertensive patients attending outpatient clinic in Lagos University Teaching Hospital, Nigeria. The Nigerian postgraduate medical journal, 26(2), 129-137. https://doi.org/10.4103/npmj.npmj_48_19

Otani, K., Waterman, B., Faulkner, K., Boslaugh, S., \& Dunagan, C. (2010). How Patient Reactions to Hospital Care Attributes Affect the Evaluation of Overall Quality of Care, Willingness to Recommend, and Willingness to Return. Journal of Healthcare Management, 55(1), 25-38.

Othman, Z. J., Hussein, H., Al-faisu, W., \& Wasty, A. (2015). Predictors of patient satisfaction among Diabetic Population Attending Primary Health care centers at Dubai Health Authority. Quality in Primary Care, 23(4): 205-213.

Rahman, M. M., Ngadan, D. P., \& Arif, M. T. (2016). Factors affecting satisfaction on antenatal care services in Sarawak, Malaysia: evidence from a cross sectional study. Springer Plus, 5, 725. https://doi.org/10.1186/s40064-016-2447-3

Saeed, A. A., Mohammed, B. A., Magzoub, M. E., \& Al-Doghaither, A. H. (2001). Satisfaction and correlates of patients' satisfaction with physicians' services in primary health care centers. Saudi medical journal, 22(3), 262-267.

Safroneeva, E., Hafner, D., Kuehni, C.E., Zwahlen, M., Trelle, S., Biedermann, L. et al., (2020). Systematic Assessment of Adult Patients' Satisfaction with Various Eosinophilic Esophagitis Therapies. International Archives of Allergy and Immunology, 181, 211-220. https://doi.org/doi:10.1159/000504846)

Shagaya, Y. J. (2015). Assessment of Student's Satisfaction and Quality of Patient Care under the Nigerian Tertiary Institutions Social Health Insurance Programme (TISHIP). European Journal of Business and Management, 7, 20-30.

Sharew, N. T., Bizuneh, H. T., Assefa, H. K., \& Habtewold, T. D. (2018). Investigating admitted patients' satisfaction with nursing care at Debre Berhan Referral Hospital in Ethiopia: a cross-sectional study. BMJ open, 8(5), e021107. https://doi.org/10.1136/bmjopen-2017-021107

Sharifi, M., Baraz, S., Mohammadi, F., Ramezani, M., \& Vardanjani, E. A. (2012). Patients Perception and Satisfaction of the Ambulance Service (115) at Shahrekord, Iran. Life Science Journal, 9(4), 2196-2201.

Surur, A. S., Teni, F. S., Girmay, G., Moges, E., Tesfa, M., \& Abraha, M. (2015). Satisfaction of clients with the services of an outpatient pharmacy at a university hospital in northwestern Ethiopia: a cross-sectional study. BMC Health Service Research, 15(1), 229. https://doi.org/10.1186/s12913-015-0900-6

Uzoagulu, E. U. (2011). Practical Guide to Written Research Project Report in Tertiary Institutions. Published and printed in Nigeria by CHESTON LTD 10 Eze street (off Edozie street) Uwani Enugu Nigeria.

Vidhya, K., \& Rajakumar, C., (2014). An empirical study on perceived service quality and patient satisfaction with special reference to puduchemy hospitals. Asia-Pacific Journal of Public Health, 2(10), 2320-5504. 
Xesfingi, S., \& Vozikis, A., (2016). Patient satisfaction with the healthcare system: Assessing the impact of socio-economic and healthcare provision factors. BMC Health Service Research, 16, 94. https://doi.org/10.1186/s12913-016-1327-4.

Xiao, H., \& Barber, J. P. (2008). The effect of perceived health status on patient satisfaction. Value Health International Society for Pharmacoeconomics and Outcomes Research (ISPOR), 11(4), 719-725. https://doi.org/doi:10.1111/j.1524-4733.2007.00294.x.

Zhang, X., Wang, T., Yu, T., \& Zhao, S. (2018). Key nodes affecting patient satisfaction in a cross-regional referral service process: an empirical analysis study in Sichuan. BMC Health Service Research, 18, 840. https://doi.org/10.1186/s12913-018-3460-8

\section{Copyrights}

Copyright for this article is retained by the author(s), with first publication rights granted to the journal.

This is an open-access article distributed under the terms and conditions of the Creative Commons Attribution license (http://creativecommons.org/licenses/by/4.0/). 